\title{
On Megalatriotrema bispidum, a new genus and new species of Microphallid Trematode from frogs in Andhra Pradesh, India.
}

\author{
Megalatriotrema bispidum n. gen. n. sp, \\ Trématode Microphallidé de Batraciens à Andhra Pradesh (Indes) \\ By Mrs. Ratnamala RAO \\ (Department of Zoology. University College of Science, Osmania University, \\ Hyderabad. India)
}

\begin{abstract}
Résumé
Vingt-trois exemplaires de Microphallidae Travassos 1920, provenant de l'intestin de bull-frogs de la variété Rana tigrina (Batraciens originaires de Gadwal et des environs d'Hyderabad) ont été récoltés.

Bien que présentant certaines ressemblances avec le genre Levinseniella Stiles and Hassall 1901 par la disposition des gonades, la forme de l'atrium génital et la distribution des vitellogènes, les distomes examinés marquent des différences sensibles dans la situation du pore génital qui s'ouvre en avant de l'acétabulum, le prépharynx peu visible et surtout la spinulation du cirre et de l'atrium génital.

La structure du cirre est d'une grande importance dans la systématique des sous-familles de Microphallidés. Son armature épineuse et celle de l'atrium génital paraissent justifier pour l'auteur la création d'une nouvelle sous-famille (Megalatriotreminae), ainsi que l'émendation en ce sens de la clé de détermination des Microphallidae établie en 1966 par S. Deblock et P. Tran Van Ky (p. 52 de ce travail).

L'auteur donne la diagnose du genre nouveau Megalatriotrema, et propose pour l'espèce type le nom de Megalatriotrema hispidum. Les spécimens en sont déposés au Zoology Museum d’Osmania University, en Inde.
\end{abstract}




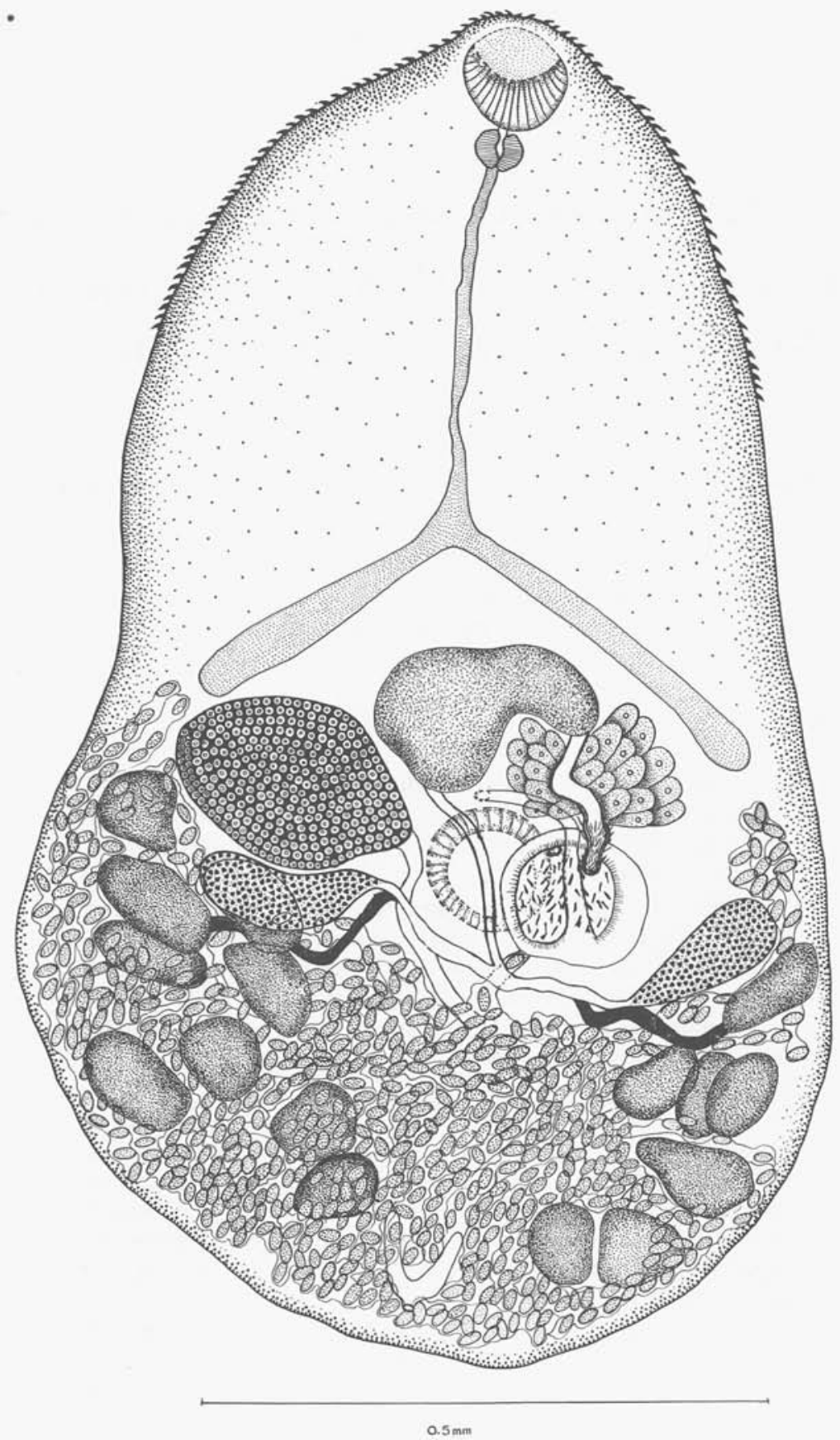

Fig. 1. - Megalotriotrema hispidum n. gen. n. sp. 


\section{Summary}

The diagnosis of a new genus of Microphallidae Megalatriotrema is given for flukes recovered from Rana tigrina in India. The name suggested for the genotype is $M$. hispidum.

The spiny armature of the cirrus along with that of the genital atrium justifies, for the A., the creation of a new subfamily, Megalatriotreminae.

The key, given by S. Deblock and P. Tran van Ky in 1966, for the Microphallidae was emended in that way.

Flukes belonging to the family Microphallidae Travassos, 1920, were recovered from a Bull-frog Rana tigrina procured from Gadwal (Dist. Mahboobnagar). As many as 22 specimens were collected from the intestine of the single specimen of the frog dissected. Subsequently an isolated fluke was again collected from a frog caught in the vicinity of Hyderabad city.

When first examined in live condition, under the microscope, the fluke looked like Levinseniella species, but detailed study of fixed and stained material revealed

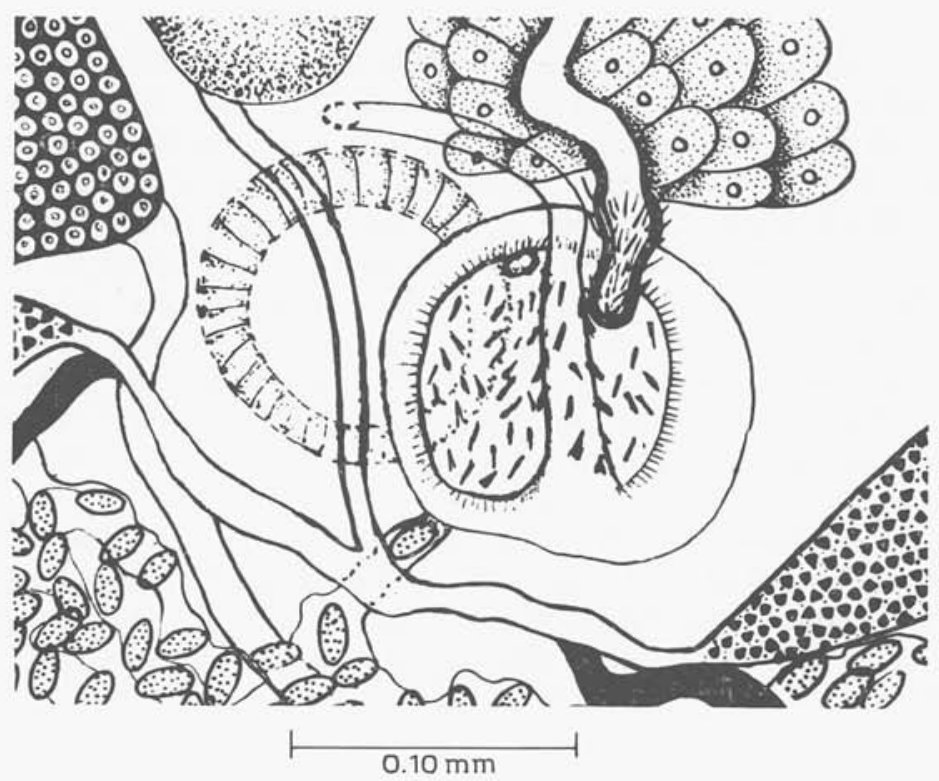

FIg. 2. - $M$. hispidum : région acétabulaire: atrium génital 
distinctive features which exclude the worm under study from all the known subfamilies of Microphallidae. These distinguishing features are : the presence of spiny armature both on the cirrus and on the lining of the genital atrium.

The flukes have an elongate-pyriform shape, narrowed anteriorly and broadly rounded posteriorly. These are rather small in size measuring $0.75-1.32 \mathrm{~mm}$. long with a maximum width of $0.51-0.82 \mathrm{~mm}$. attained in the posterior half of the body. The cuticle is armed with spines which extend over the entire body surface. The oral sucker is subterminal, measuring $0.07-0.1 \mathrm{~mm}$. in diameter. The acetabulum, which is slightly larger in size than the oral sucker, measures $0.11-0.15 \mathrm{~mm}$. in diameter ; and is located posterior to middle of the body. The mouth is surrounded by the oral sucker posterior to which lies an inconspicuous prepharynx leading into a small circular pharynx $0.026-0.06 \mathrm{~mm}$. in diameter. The oesophagus which follows is a long tube being roughly one third the postpharyngeal length of the body ; it divides into the paired caeca which run backwards and outwards to the equatorial level of the body.

$A$ \& $\mathrm{V}$-shaped excretory vesicle is present which opens by means of a short duct at the ventrally situated subterminal excretory pore. The testes, measuring $0.15-0.29 \mathrm{~mm}$. by $0.05-0.12 \mathrm{~mm}$., are symmetrical and transversely placed club-shaped structures projecting partly into the acetabular level; the left one is located close behind the ovary. The two vasa efferentia run inwards towards the middle of the body to form a common vas deferens which runs anteriorly to open into a prominent seminal vesicle. The latter, lying transversely, occupies a median preacetabular position and measures $0.15-0.297 \mathrm{~mm}$. by $0.074-0.18 \mathrm{~mm}$. From its apex runs posteriorly a ductus ejaculatorius, surrounded by a distinct pars prostatica, beyond which it is continued into the cirrus. A cirrus pouch is lacking. The cirrus, which is armed with a series of backwardly directed spines, projects into a prominent genital atrium. The atrium is slightly bigger in size than the acetabulum and is characterized by the presence of distinct spines. The ovary is a massive structure lying to the left of the acetabulum. It is oval in shape with smooth borders and measures $0.14-0.32 \mathrm{~mm}$. by $0.07-0.16 \mathrm{~mm}$. The oviduct arising from its inner margin runs posteriorly alongside the acetabulum towards the oötype. The uterus emerging from the latter is thrown into transverse coils which occupy all the available space of the body behind the gonads. The vitellaria form large follicular masses numbering 7 to 9 on either side and lie posterior to the level of the ovary, with some of them overlapping the testes. Transverse vitelline ducts run towards the median line to open into the oviduct near the oötype. The metraterm opens into the genital atrium close to its front border. The genital atrium is produced into a common genital duct which opens to the exterior immediately in front of the acetabulum. The fully developed eggs lying in the coils of the uterus next to the metraterm measure $0.14-0.24 \mathrm{~mm}$. by $0.06-0.16 \mathrm{~mm}$. 


\section{Discussion}

The fluke described above could not be assigned to any of the known subfamilies of the family Microphallidae. It, however, shows some resemblance to the genus Levinseniella Stiles and Hassall, 1901, belonging to Microphallinae. The features revealing this affinity are : a somewhat similar disposition of the gonads, the genital atrium and distribution of the vitellaria. It differs markedly from the genus Levinseniella in the position of its genital aperture which lies anterior to the acetabulum. Other distinguishing features are: Prepharynx, which is distinct in Levinseniella, is inconspicuous in the new form. Oral sucker is larger than acetabulum in Levinseniella, whereas in the newly found fluke, the acetabulum is subequal and even slightly larger in size than the oral sucker. The most important character exhibited by the present form is the presence of backwardly directed spines on the cirrus and also in the genital atrium. Such features have not been described in any Microphallid known so far.

The structure of cirrus is of great systematic importance and its varying shape forms the main basis for the division of the family into subfamilies. Therefore, the spiny armature of the cirrus along with that of the genital atrium justifies the creation of a new subfamily.

The key given by S. Deblock and P. Tran Van Ky, 1966, for differentiating the subfamilies is amended as follows:

\section{KEY}

1. Cirrus and genital atrium armed with spines.

Megalatriotreminae sub-fam. nov.

Cirrus and genital atrium unarmed.

2

2. Cirrus pouch present.

Maritreminae Lal, 1939.

Cirrus pouch absent.

3

3. Vesiculo-prostatic pouch absent. Seminal vesicle and pars prostatica free in the parenchyma.

Microphallinae Ward, 1901.

Vesiculo-prostatic pouch present.

4

4. Cirrus enclosed in genital atrium.

Gynaecotylinae Guschanskaia, 1952.

Cirrus enclosed in a «Phallosphere» distinctly set off from vesiculo-prostatic pouch and genital atrium.

Sphairiotreminae Deblock et Tran Van Ky, 1966.

Diagnosis of Megalatriotrema nov. gen. : Small, pyriform flukes; body cuticle armed with spines ; oral sucker subterminal ; acetabulum posterior to middle of body, slightly larger than oral sucker; prepharynx inconspicuous; oesophagus long and slender; caeca short, terminating at mid level of the body. Excretory vesicle 
«V »-shaped. Ovary lateral to acetabulum and immediately anterior to left testis. Vitellaria post acetabular, forming large follicular masses, 7 to 9 on either side. Cirrus pouch absent; Seminal vesicle large and located in front of acetabulum ; pars prostatica distinct; cirrus armed with spines, projecting into a well developed spiny genital atrium partly overlapped by acetabulum; genital duct opening immediately anterior to acetabulum.

\section{GÉNOTYPE :}

Megalatriotrema hispidum parasitic in Rana tigrina.

Habitat : Intestine.

Locality: Gadwal, Hyderabad, A.P., India.

Type specimens are deposited in the Zoology Museum, Osmania University.

\section{ACKNOWLEDGEMENTS :}

The author wishes to express her gratitude to Prof. S. N. Singh, for his valuable guidance and the facilities provided by him.

\section{Références}

1. Deblock (S.) et Tran Van Ky (P.), 1966. - Contribution à l'étude des Microphallidae Travassos, 1920 (Trematoda). XII. Espèces d'Europe occidentale. Création de Sphairiotrema nov. gen. ; considérations diverses de systématique. Ann. parasitol. hum. et comp., 41 , pp. 23-60.

2. Skrjabin (K.-I.), 1952. - Trematodes of animals and men. Principals of trematodology, vol VI, Moscow, u. Leningrad. Publ. Acad. Sci., U.S.S.R.

3. YAmaguti (S.), 1958. - Systema Helminthum. Volume I, the digenetic Trematodes of Vertebrates. Part I., New York. Inter Science Publishers, Inc. 